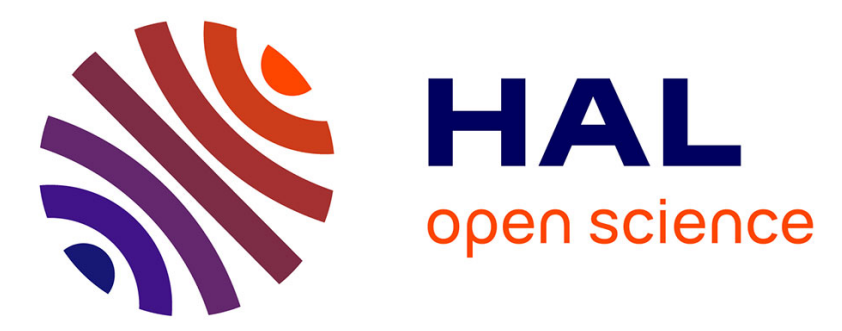

\title{
Sliding Wear Response of Nanostructured YSZ Suspension Plasma-Sprayed Coating
}

S. Kossman, D. Chicot, Xavier Decoopman, Alain Iost, Adrien van Gorp, Erick Meillot, Eli Saúl Puchi-Cabrera, Y.Y. y Santana, M.H. H Staia

\section{- To cite this version:}

S. Kossman, D. Chicot, Xavier Decoopman, Alain Iost, Adrien van Gorp, et al.. Sliding Wear Response of Nanostructured YSZ Suspension Plasma-Sprayed Coating. Journal of Thermal Spray Technology, 2014, 23 (8), pp.1350-1361. 10.1007/s11666-014-0146-6 . hal-01170447

\section{HAL Id: hal-01170447 \\ https://hal.science/hal-01170447}

Submitted on 10 Oct 2017

HAL is a multi-disciplinary open access archive for the deposit and dissemination of scientific research documents, whether they are published or not. The documents may come from teaching and research institutions in France or abroad, or from public or private research centers.
L'archive ouverte pluridisciplinaire HAL, est destinée au dépôt et à la diffusion de documents scientifiques de niveau recherche, publiés ou non, émanant des établissements d'enseignement et de recherche français ou étrangers, des laboratoires publics ou privés. 


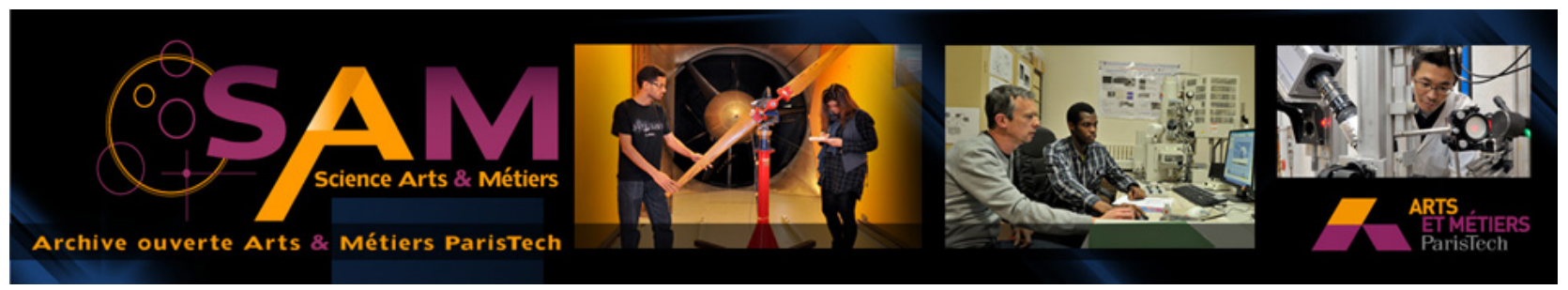

\section{Science Arts \& Métiers (SAM)}

is an open access repository that collects the work of Arts et Métiers ParisTech researchers and makes it freely available over the web where possible.

This is an author-deposited version published in: http://sam.ensam.eu

Handle ID: .http://hdl.handle.net/null

\section{To cite this version :}

S KOSSMAN, Xavier DECOOPMAN, Didier CHICOT, Alain IOST, Adrien VAN GORP, E MEILLOT, E.S. PUCHI CABRERA, YY SANTANA, MH STAIA - Sliding Wear Response of Nanostructured YSZ Suspension Plasma-Sprayed Coating - Journal of Thermal Spray Technology - Vol. 23, n8, p.1350-1361 - 2014 


\title{
Sliding Wear Response of Nanostructured YSZ Suspension Plasma-Sprayed Coating
}

\author{
S. Kossman, D. Chicot, X. Decoopman, A. lost, A. van Gorp, E. Meillot, E.S. Puchi-Cabrera, \\ Y.Y. Santana, and M.H. Staia
}

(Submitted March 25, 2014; in revised form July 26, 2014)

\begin{abstract}
Nanostructured yttria-stabilized zirconia coatings for applications in high-temperature environments can be deposited by suspension plasma spraying (SPS) techniques. The present research has been conducted in order to study the sliding wear response of a SPS $\mathrm{ZrO}_{2}-8 \% \mathrm{~mol} . \mathrm{Y}_{2} \mathrm{O}_{3}$ coating $(75 \mu \mathrm{m}$ in thickness) deposited onto a Haynes 230 substrate, using pin-on-disc tests. Some of the coated samples were subsequently heat-treated for $1 \mathrm{~h}$ at 300 and $600^{\circ} \mathrm{C}$. Samples characterization prior and after the wear tests was carried out by SEM, EDS, XRD and optical profilometry techniques. Instrumented indentation was employed to determine elastic modulus and hardness. The results have shown that the as-sprayed and heat-treated samples experienced severe wear $\left(10^{-13} \mathrm{~m}^{3} / \mathrm{Nm}\right)$ and the worst wear performance corresponded to the sample heat treated at $600{ }^{\circ} \mathrm{C}$. Such a behavior could be related to both the structural changes that took place during heat treatment and the nature and level of the residual stresses in the coatings. In general, the morphologies of the wear tracks observed by SEM have shown a smoothing of the surface, brittle fracture, smearing and grain pull-out.
\end{abstract}

Keywords heat treatment, nanoindentation, nanostructured coating, suspension plasma spray, wear, yttriastabilized zirconia

\section{Introduction}

As industry develops, the need of new materials that can withstand more severe and critical conditions has become a major concern. Currently, there is a special interest in the manufacture of finely structured coatings (nanometric or sub-micrometric sized) for industrial applications. Many of the new developed technologies include these coatings in their designs due to their industrially recognized benefits on mechanical properties, as well as corrosion and wear resistance under high-temperature environments. Some of the most common applications for these coatings are environmental barriers for

S. Kossman, School of Metallurgical Engineering and Materials Science, Faculty of Engineering, Universidad Central de Venezuela, 47885, Los Chaguaramos, Caracas 1041, Venezuela and Laboratoire de Mécanique de Lille, LML, UMR 8107, UST Lille, IUT A GMP, BP 90179, 59653 Villeneuve d_Ascq, France; D. Chicot and X. Decoopman, Laboratoire de Mécanique de Lille, LML, UMR 8107, UST Lille, IUT A GMP, BP 90179, 59653 Villeneuve d_Ascq, France; A. Lost and A. Van Grop, Arts et Métiers ParisTech, MSMP, 8, Boulevard Louis XIV, 59000 Lille Cedex, France; E. Meillot, CEA, DAM, Le Ripault, 37260 Monts, France; E.S. Puchi-Cabrera, School of Metallurgical Engineering and Materials Science, Faculty of Engineering, Universidad Central de Venezuela, 47885, Los Chaguaramos, Caracas 1041, Venezuela and Laboratoire de Mécanique de Lille, LML, UMR 8107, UST Lille, IUT A GMP, BP 90179, 59

photocatalytic applications, electric insulation for solar energy generators, thermal insulation in industrial gas turbines and aero turbines, and ionic and electronic conductors for solid oxy-fuel cells, amongst others (Ref 1,2). Many studies have revealed that decreasing the scale of the coating structure to the nanometer scale during thermal spray processing leads to a considerable improvement of mechanical properties and tribological behavior regarding friction coefficient and wear rate, in comparison with conventional coatings (Ref 3-7).

Suspension plasma spraying (SPS) is a relatively new plasma spray process that has been used in the last 10 years, that allows the possibility of elaborating thinner coatings, which exhibit either nanometer or submicrometer sized architecture, in comparison with those resulting from the traditional processing. This method consists in mixing nanometric or sub-micrometric particles with a liquid carrier phase, usually distilled water or ethanol and some dispersant to maintain the suspension stability and avoid agglomeration. The suspension is injected

653 Villeneuve d_Ascq, France and Venezuelan National Academy for Engineering and Habitat, Palacio de las Academias, 1723, Caracas 1010, Venezuela; Y.Y. Santana, School of Metallurgical Engineering and Materials Science, Faculty of Engineering, Universidad Central de Venezuela, 47885, Los Chaguaramos, Caracas 1041, Venezuela; M.H. Staia, School of Metallurgical Engineering and Materials Science, Faculty of Engineering, Universidad Central de Venezuela, 47885, Los Chaguaramos, Caracas 1041, Venezuela, Arts et Métiers ParisTech, MSMP, 8, Boulevard Louis XIV, 59000 Lille Cedex, France and Venezuelan National Academy for Engineering and Habitat, Palacio de las Academias, 1723 Caracas 1010, Venezuela 1041, Venezuela. Contact e-mail: stephaniakossman@gmailcom. 
into the plasma jet and can be deposited over low roughness substrates (Ref 8-11).

SPS coatings exhibit a granular morphology consisting of two grain types. On the one hand, there is a mixture of melted and unmelted particles, which have the shape of the original feedstock particles and which travel in the colder regions of the plasma flow. On the other hand, there are small spherical grains, which correspond to remelted particles before their impact upon the substrate. This morphology differs considerably from the typical anisotropic lamellar structure that characterizes the traditional atmospheric plasma spraying (APS) coatings (Ref 8, 10, 12). Currently, yttria-stabilized zirconia (YSZ) coatings are widely used for thermal barrier coatings (TBCs) as well as solid oxide fuel cells (SOFCs) applications, due to properties like high hardness, wear resistance, ion conductivity, thermal expansion coefficient similar to superalloys, etc., which in turn depend on the coating architecture, i.e. if it is porous or dense, respectively (Ref 9, 12-14).

Zirconia is a polymorphic ceramic material, which exists in three well-known structural forms: monoclinic, tetragonal and cubic. It is often doped with $\mathrm{Y}_{2} \mathrm{O}_{3}$ (yttria) or other oxides to avoid its spontaneous transformation (Ref 15, 16). It has been shown that yttria partially stabilized zirconia (YPSZ) nanostructured coatings deposited by APS exhibit enhanced properties such as increased wear resistance, bond strength and microhardness, in comparison with the conventional coatings of the same composition (Ref 5, 8, 17).

The tribological behavior of YSZ coatings is very sensitive to the microstructure, especially to porosity, microcracking and inclusions present in the as-sprayed (AS) condition. Also, chemical properties of ceramics have an important role in the wear behavior since their reactions with humidity can cause zirconia embrittlement (Ref 18, 19). Moreover, a strong dependence on temperature has been determined, changing from a low to a high wear regime with the increase of temperature and sliding speed. Earlier studies pointed out that the wear mechanisms of traditional plasma-sprayed zirconia coatings could be severe fracture, grain pull-out, smearing of the worn material, fatigue spalling, plastic deformation and material transfer, depending on the nature of the material and testing conditions (Ref 17, 20, 21).

For most of the YSZ coatings applications, the control of phase composition is imperative for optimal lifetime. Larger amounts of the monoclinic phase are undesirable, since, on heating, this transforms into the tetragonal phase, accompanied by a large volume change, leading to premature failure. Coatings made of fully stabilized zirconia (cubic phase) have shorter lifetimes and generally inferior properties as compared to partially stabilized zirconia coatings (cubic matrix with grains of tetragonal phase) (Ref 22).

The present work aims at studying the tribological behavior of nanostructured YSZ coatings deposited by SPS (using nanoparticles) at room temperature, regarding their phase composition, heat treatment and testing conditions.

\section{Experimental Procedure}

\subsection{Materials}

The coated samples were supplied by the Commissariat à l'Énergie Atomique et aux Énergies Alternatives (CEA) in France. The YSZ coatings were deposited by SPS. The suspension was prepared by using $8 \mathrm{YSZ}\left(\mathrm{ZrO}_{2}-8 \% \mathrm{~mol}\right.$. $\mathrm{Y}_{2} \mathrm{O}_{3}$ ) nanometric powders of 30 to $60 \mathrm{~nm}$ particle size, provided by Inframat (Willington, CT, USA) and distilled water as solvent. The suspension was mechanically mixed and ultrasonically stirred to break up the agglomerates without dispersants. The concentration of solid particles in the suspension was $6 \mathrm{wt} . \%$. The thickness of the coatings was approximately $75 \mu \mathrm{m}$ and the corresponding spray parameters are shown in Table 1.

Cylindrical samples of $30 \mathrm{~mm}$ diameter and $3 \mathrm{~mm}$ thickness made of Haynes 230 (Ni 57\%, Cr 22\%, W 14\%, Mo 2\%, and $\mathrm{Fe}$ max. 3\%) as substrate were employed. Before coating deposition, the samples were ultrasonically cleaned with acetone and alcohol without any prior grit blasting. The average roughness of the substrate before deposition was $0.9 \mu \mathrm{m}$. No metallic bond coat was used between the substrate and YSZ coating.

\subsection{Heat Treatments}

Some of the coated samples were heat treated for $1 \mathrm{~h}$ at 300 and $600{ }^{\circ} \mathrm{C}$, respectively, and subsequently furnace cooled to room temperature, to prevent cracking. These samples will be designated as TT-300 ${ }^{\circ} \mathrm{C}$ and TT-600 ${ }^{\circ} \mathrm{C}$ in the following sections.

\subsection{Coatings Characterization}

The YSZ coatings surfaces of the AS and heat-treated samples were observed employing SEM techniques in a secondary electron mode (SE). In addition, cross-section views of the coating after fracture were also analyzed. This procedure is similar to that applied to thin hard coatings deposited on metallic substrates in order to allow the observation of the actual coating architecture. Elemental analysis of the samples was carried out using energy dispersive spectroscopy (EDS) techniques coupled with SEM observations.

The phases present in the YSZ coatings were identified by means of X-ray diffraction (XRD) techniques, employing a Siemens D5000 diffractometer with a Co-K $\alpha$ radiation $(\lambda=1.78897), 0.02^{\circ}$ scanning step size, $4 \mathrm{~s}$ count time per step and a $2 \Theta$ angle range between $25^{\circ}$ and $125^{\circ}$. The surface roughness of the coatings was measured by means of optical profilometry, using a Veeco Wyko NT9300 profilometer.

The mechanical characterization of the AS and heattreated samples (TT-300 ${ }^{\circ} \mathrm{C}$ and TT- $600{ }^{\circ} \mathrm{C}$ ) was carried out by means of instrumented indentation techniques. Nanoindentation experiments were performed with a $\mathrm{XP}^{\mathrm{TM}}$ Nano Indenter (MTS Nano Instruments, MN, USA) employing a Berkovich diamond indenter. For this purpose, the nanostructured coated sample was fixed on a metallic support using the heat softening glue crystal bond 
Table 1 Suspension plasma spraying (SPS) parameters

Plasma torch

Anode diameter, $\mathrm{mm}$

Plasma gas

Plasma gas flow rate, slim

Arc current, A

Feedstock injection

Spray distance, $\mathrm{mm}$

Plasma gun traverse speed, $\mathrm{m} / \mathrm{s}$

Plasma gun scanning step, $\mathrm{mm}$

Deposition cycles $75 \mu \mathrm{m}$

Pre-heating temperature substrate, ${ }^{\circ} \mathrm{C}$

\section{F4-VB Sulzer-Metco}

6

$\mathrm{Ar} / \mathrm{He} / \mathrm{H}_{2}$

$45 / 45 / 3$

700

Liquid pressure: 3.2 bar

Nozzle diameter: $250 \mu \mathrm{m}$ 40

1.5

5

150

400
509. Twenty-five indentation tests were conducted randomly at the surface of the material under the same indentation testing conditions. The maximum indentation depth reached by the indenter was fixed at approximately $2000 \mathrm{~nm}$ and the strain rate was equal to $0.05 \mathrm{~s}^{-1}$. The instrument was operated in the continuous stiffness measurement (CSM) mode allowing the calculation of the elastic modulus and the hardness continuously during the indentation loading-unloading cycle. The harmonic displacement was $2 \mathrm{~nm}$ and the frequency was $45 \mathrm{~Hz}$. The properties were determined employing the methodology advanced by Oliver and Pharr (Ref 23, 24).

\subsection{Tribological Characterization}

Sliding wear tests were conducted employing a CSM ball on disc tribometer. YSZ coatings in the AS condition were tested against an alumina $\left(\mathrm{Al}_{2} \mathrm{O}_{3}\right)$ counterpart of $6 \mathrm{~mm}$ in diameter, at 2 and $5 \mathrm{~N}$ normal loads, both at room temperature. All the tests were performed at $0.1 \mathrm{~m} / \mathrm{s}$ sliding velocity and for 7960 laps without lubrication. The sliding distance used was $500 \mathrm{~m}$ for a $2 \mathrm{~N}$ normal load and $300 \mathrm{~m}$ for $5 \mathrm{~N}$. Samples heat treated at 300 and $600{ }^{\circ} \mathrm{C}$ were tested under the same conditions of load, sliding velocity and number of laps.

Wear tracks were characterized by optical profilometry and SEM to elucidate the wear mechanisms. Wear volumes and wear constants were determined by measuring linear profiles across the width of wear tracks by optical profilometry at eight different points. Subsequently, the area was computed by the integration of the curve described by a piecewise cubic spline. According to Archard's law, the wear volume and wear constant were calculated by means of the following equations:

$V_{\text {wear }}=A_{\text {st }} 2 R_{\mathrm{t}}$,

$K_{\mathrm{w}}=A_{\mathrm{st}} 2 R_{\mathrm{t}} /(P S)\left(\mathrm{m}^{3} / \mathrm{Nm}\right)$,

where $V_{\text {wear }}$ represents the wear volume, $A_{\text {st }}$ the crosssectional area of wear track, $R_{\mathrm{t}}$ the contact radius, $K_{\mathrm{w}}$ is the wear constant $\left(\mathrm{m}^{3} / \mathrm{Nm}\right), P$ is the normal load $(\mathrm{N})$ and $S$ is the sliding distance $(\mathrm{m})$.

The worn samples were also evaluated by means of XRD techniques in order to determine the occurrence of any variation of the initial existing phases during the tests.

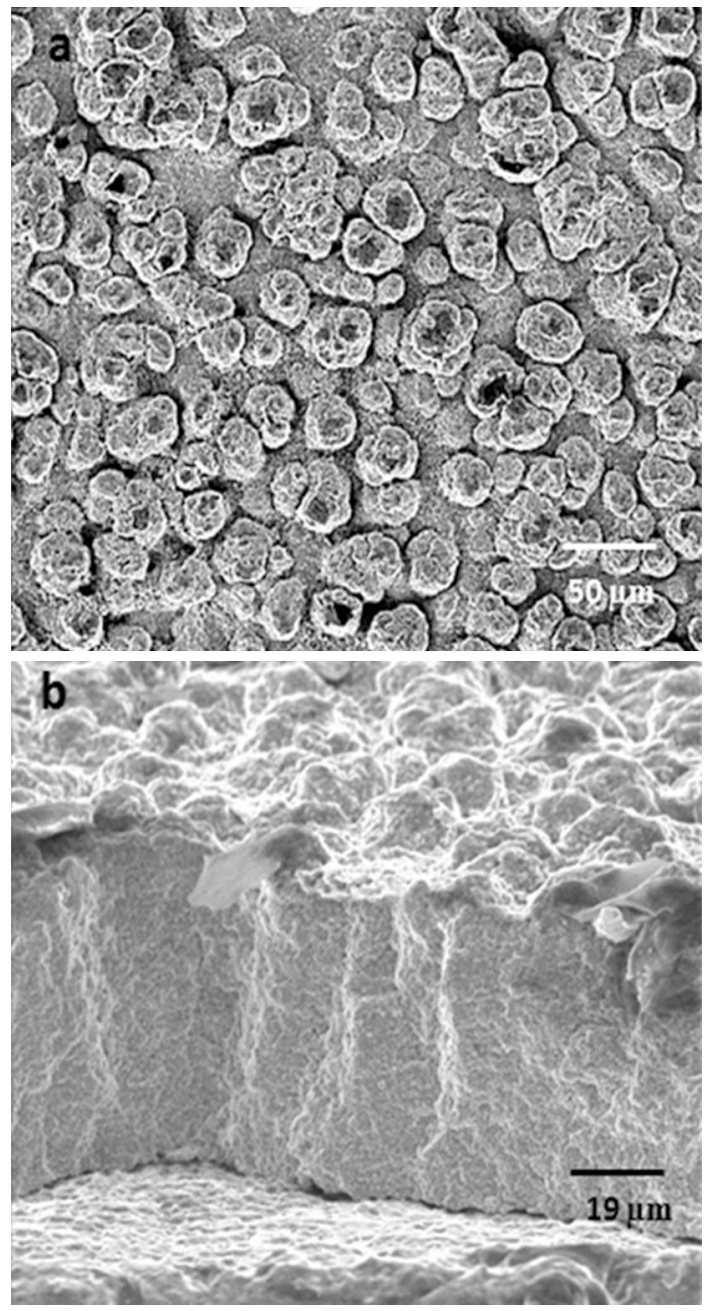

Fig. 1 YSZ coating: a top view of the coating surface. b Crosssection view of the coating after fracture

\section{Experimental Results}

\subsection{Microstructural and Morphological Properties}

SEM morphologies of both the coating top surface and cross-section surface after fracture, shown in Fig. 1, illustrate that the coatings exhibit a granular morphology (Fig. 1a), similar to cauliflower formations, as mentioned 

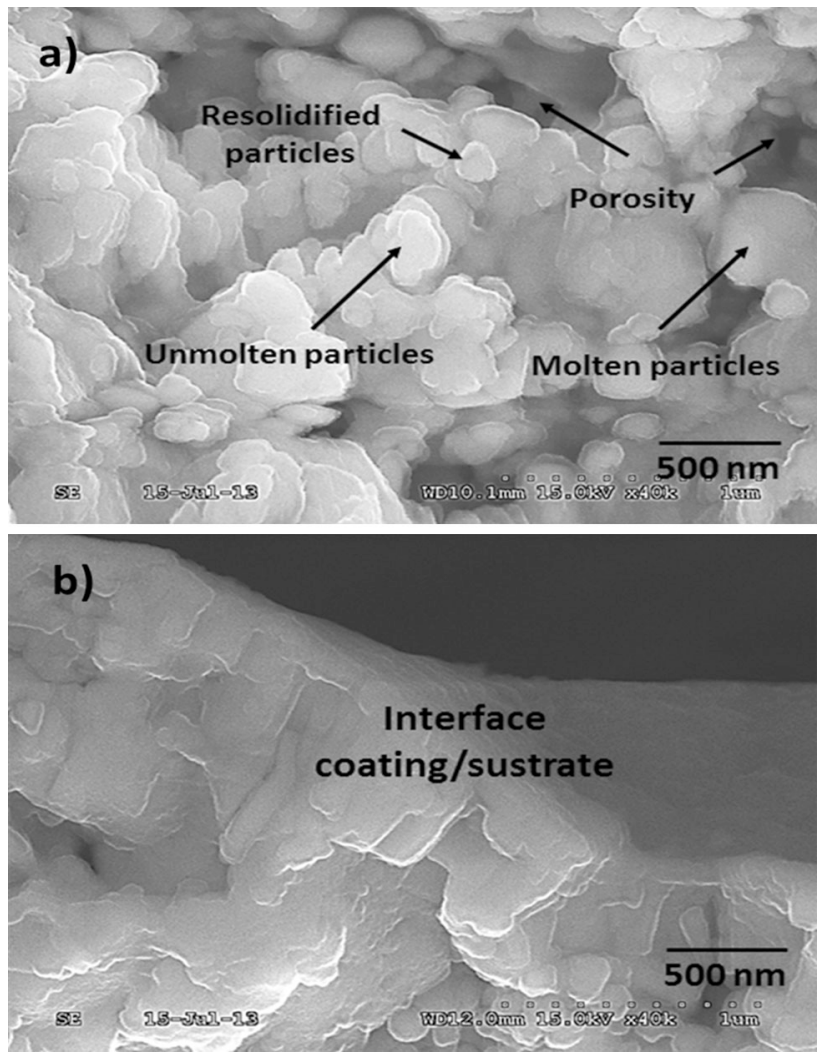

Fig. 2 SEM of the cross-section view of the coatings after fracture: a upper part of the coating, $\mathbf{b}$ near the substrate/coating interface. A thin columnar layer followed by a granular layer can be observed

Table 2 Analysis by EDS of YSZ coating

\begin{tabular}{lccc}
\hline$\%$ & $\mathbf{Z r}$ & $\mathbf{Y}$ & $\mathbf{O}$ \\
\hline Weight & 59.4 & 10.1 & 30.5 \\
Atoms & 24.4 & 4.3 & 71.3 \\
\hline
\end{tabular}

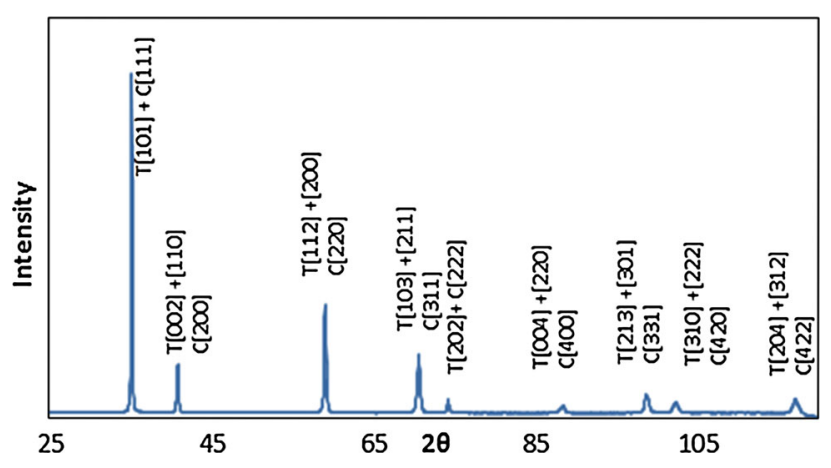

Fig. 3 XRD pattern of YSZ coating in as-sprayed condition

by VanEvery et al. (Ref 25), as a result of the stacked grains. Some columnar stacking defects are also noticed from the micrograph shown in Fig. $1 \mathrm{~b}$.

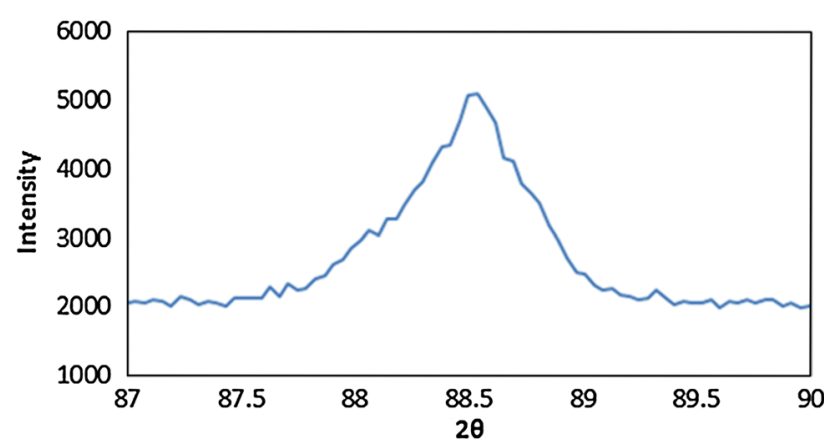

Fig. 4 Detailed X-ray diffraction pattern in the region of the diffraction angles $2 \Theta=87^{\circ}$ to $90^{\circ}$ for the as-sprayed coating
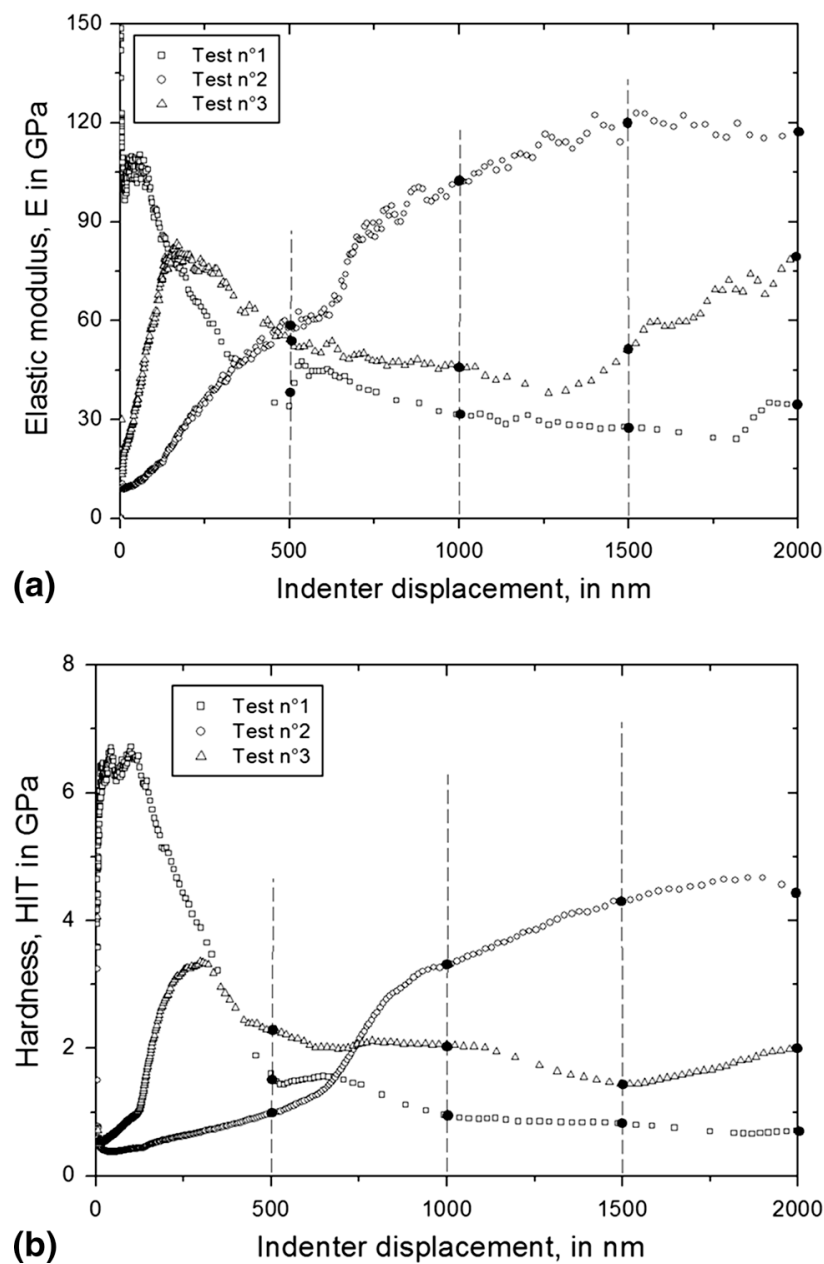

Fig. 5 Examples of the variation of the mechanical properties vs. indenter displacement for the as-sprayed polished sample, with a roughness $\left(R_{\mathrm{a}}\right)$ of $2 \mu \mathrm{m}$ : a elastic modulus, $\mathbf{b}$ hardness

Figure 2 illustrates more detailed SEM micrographs of the cross-section view of the coatings after fracture and allows the observation of a thin columnar layer at the substrate/coating interface, which transforms into a granular morphology as the coating distance from the surface increases. Also, in Fig. $2 \mathrm{~b}$, it can be noticed that the columnar stacking defects shown in Fig. 1b, present 
Table 3 Mean values of the elastic modulus and the hardness measured at given indenter displacements for the different coated systems and heat treatments

\begin{tabular}{|c|c|c|c|c|c|}
\hline \multirow[b]{2}{*}{ Coated system } & \multicolumn{4}{|c|}{ Indenter displacement, nm } & \multirow[b]{2}{*}{ Mean value } \\
\hline & 500 & 1000 & 1500 & 2000 & \\
\hline \multicolumn{6}{|l|}{ AS-NP $(6 \mu \mathrm{m})$} \\
\hline $\mathrm{E}, \mathrm{GPa}$ & $34 \pm 21$ & $35 \pm 18$ & $38 \pm 21$ & $44 \pm 22$ & 38 \\
\hline $\mathrm{HIT}, \mathrm{GPa}$ & $1.2 \pm 0.6$ & $1 \pm 0.6$ & $0.9 \pm 0.4$ & $0.9 \pm 0.4$ & 1 \\
\hline \multicolumn{6}{|l|}{ AS-P $(1 \mu \mathrm{m})$} \\
\hline $\mathrm{E}, \mathrm{GPa}$ & $47 \pm 21$ & $48 \pm 13$ & $47 \pm 17$ & $49 \pm 19$ & 48 \\
\hline HIT, GPa & $1.7 \pm 1.1$ & $1.4 \pm 0.6$ & $1.3 \pm 0.5$ & $1.2 \pm 0.7$ & 1.4 \\
\hline \multicolumn{6}{|l|}{ AS-P $(2 \mu \mathrm{m})$} \\
\hline $\mathrm{E}, \mathrm{GPa}$ & $33 \pm 18$ & $38 \pm 13$ & $44 \pm 13$ & $48 \pm 19$ & 41 \\
\hline HIT, GPa & $1.2 \pm 0.8$ & $1.0 \pm 0.6$ & $1.0 \pm 0.4$ & $1.1 \pm 0.5$ & 1.1 \\
\hline \multicolumn{6}{|c|}{ TT300 ${ }^{\circ} \mathrm{C}-\mathrm{P}(0.5 \mu \mathrm{m})$} \\
\hline $\mathrm{E}, \mathrm{GPa}$ & $63 \pm 20$ & $64 \pm 18$ & $68 \pm 19$ & $69 \pm 14$ & 66 \\
\hline HIT, GPa & $2.2 \pm 1.5$ & $2.1 \pm 1.3$ & $2.4 \pm 1.4$ & $2.4 \pm 1.2$ & 2.3 \\
\hline \multicolumn{6}{|c|}{ TT300 ${ }^{\circ} \mathrm{C}-\mathrm{P}(1 \mu \mathrm{m})$} \\
\hline $\mathrm{E}, \mathrm{GPa}$ & $52 \pm 17$ & $45 \pm 12$ & $43 \pm 14$ & $46 \pm 15$ & 46 \\
\hline HIT, GPa & $2.2 \pm 1.1$ & $1.4 \pm 0.5$ & $1.1 \pm 0.4$ & $1.0 \pm 0.5$ & 1.4 \\
\hline \multicolumn{6}{|c|}{ TT600 ${ }^{\circ} \mathrm{C}-\mathrm{P}(2 \mu \mathrm{m})$} \\
\hline $\mathrm{E}, \mathrm{GPa}$ & $61 \pm 26$ & $55 \pm 21$ & $56 \pm 20$ & $59 \pm 22$ & 58 \\
\hline HIT, GPa & $3.0 \pm 2.1$ & $2.4 \pm 1.5$ & $1.9 \pm 1.0$ & $1.8 \pm 1.0$ & 2.3 \\
\hline \multicolumn{6}{|c|}{ TT600 ${ }^{\circ} \mathrm{C}-\mathrm{P}(3 \mu \mathrm{m})$} \\
\hline $\mathrm{E}, \mathrm{GPa}$ & $58 \pm 22$ & $45 \pm 20$ & $41 \pm 18$ & $43 \pm 20$ & 47 \\
\hline HIT, GPa & $1.9 \pm 1.3$ & $1.6 \pm 1.2$ & $1.4 \pm 0.9$ & $1.4 \pm 0.7$ & 1.6 \\
\hline
\end{tabular}

Values inside the parenthesis indicate the roughness $\left(R_{\mathrm{a}}\right)$ of the coatings before polishing $(\mathrm{NP})$ and after polishing $(\mathrm{P})$. As-sprayed non polished (AS-NP), as-sprayed polished (AS-P), heat treated at $300{ }^{\circ} \mathrm{C}$ polished $\left(\mathrm{TT} 300{ }^{\circ} \mathrm{C}-\mathrm{P}\right)$, heat treated at $600{ }^{\circ} \mathrm{C}$ polished $\left(\mathrm{TT} 600{ }^{\circ} \mathrm{C}-\mathrm{P}\right)$

across the coating thickness, originated mostly from stacking defects in the columnar layer at the substrate/ coating interface, in agreement with the findings reported in the literature ( $\operatorname{Ref} 12,25)$. The morphologies shown in Fig. 2 have been observed before by different authors (Ref 8, 12,13), who explained in detail the influence of the operating parameters on the coating architecture. These authors considered that the columnar layer is a result of the stacking process of YSZ splats, when the heat flux is controlled by the difference in temperature between the substrate (pre-heated at $400{ }^{\circ} \mathrm{C}$ ) and the deposited material, which can usually reach between 700 and $800{ }^{\circ} \mathrm{C}$. In these conditions, the columnar layer could act as an insulating layer, delaying the heat flux to the substrate and, therefore, modifying the solidification kinetic of the impacting material. As a consequence, a granular morphology is produced since it has been considered that the flattening particles spend a longer time in a molten state where they undergo recoil, allowing the formation of smaller size droplets, due to the high surface energy and surface tension. As a result, porosity and voids are also observed, which decrease with the distance from the coating surface towards the coating/substrate interface. In a recent study, Vert (Ref 26) found a value of approximately $12 \%$ of porosity for the same coated systems as those investigated in the present work. Also, as shown in Fig. 2a, different particles including unmelted, melted and re-solidified particles can be observed. The presence of these particles is due to variations in the deposition conditions, such as changes in arc voltage, presence of plasma jet fringes, differences in feedstock particle size distribution, etc., as described by Tingaud et al. (Ref 10). As a result, the coating morphology is highly heterogeneous.

The average roughness $\left(R_{\mathrm{a}}\right)$ measured by optical profilometry for all the samples was $R_{\mathrm{a}}=5.9 \pm 1.6 \mu \mathrm{m}$. The chemical analysis conducted on the initial sample by means of EDS gives the composition of the YSZ coating shown in Table 2, indicating that these coatings contain $8 \%$ mol. $\mathrm{Y}_{2} \mathrm{O}_{3}$.

The X-ray spectrum corresponding to the AS sample (Fig. 3) nidicates the presence of both tetragonal and cubic phases identified with the XRD patterns PDF2005.4CA:01-070-4436 (cubic phase) and PDF2005.4CA:01-070-4430 (tetragonal phase). No evidence of the monoclinic phase was observed. However, the distinction between the tetragonal and cubic phases is really difficult because almost all reflections appear at similar $2 \Theta$ values. Nevertheless, there are particular values for the diffraction angles $\left(87^{\circ}\right.$ to $90^{\circ}$ and above $130^{\circ}$ for $\mathrm{CoK} \alpha_{1}=0.1789 \mathrm{~nm}$ ) in the XRD spectrum that allow an explanation of the difference between these two phases (Ref 27, 28).

Figure 4 illustrates the XRD pattern in the $2 \Theta$ region of $87^{\circ}$ to $90^{\circ}$, indicating that no doublets corresponding to the tetragonal phase $(t)$ or a very sharp peak, related to the cubic phase $(c)$, are present. The shape of the XRD pattern implies the existence of a mixture of both phases, due to the broad and asymmetric profile, as has been reported elsewhere (Ref 28). According to the yttria percentage in the coating composition of $8 \% \mathrm{~mol}$, the tetragonal phase could correspond either to an 
untransformable $\left(t^{\prime}\right)$ tetragonal phase, or to a non-transformable tetragonal phase $\left(t^{\prime \prime}\right)$. The former is a metastable phase even at high temperature, which does not transform to the monoclinic phase. The latter $\left(t^{\prime \prime}\right)$ has a tetragonality close to unit, where oxygen atoms are displaced all along $c$ axis from the ideal sites in fluorite cubic phase. Regarding the cubic phase, various authors have identified its presence for the same $\mathrm{Y}_{2} \mathrm{O}_{3}$ concentration as that found in this investigation ( $\operatorname{Ref} 29-31)$.

\subsection{Mechanical Properties}

As observed from the SEM micrographs presented above, the nanostructured YSZ coating exhibits pores and different types of particles, which have a significant influence on the characterization of the mechanical properties by indentation methods, as shown in below. Figure 5 illustrates some examples of the variation in the elastic modulus and hardness as a function of the indenter displacement, determined during the indentation experiments carried out on the AS polished sample $(\mathrm{Ra}=2 \mu \mathrm{m})$. It should be noted that these figures illustrate the behavior found in all the tests performed during this investigation,
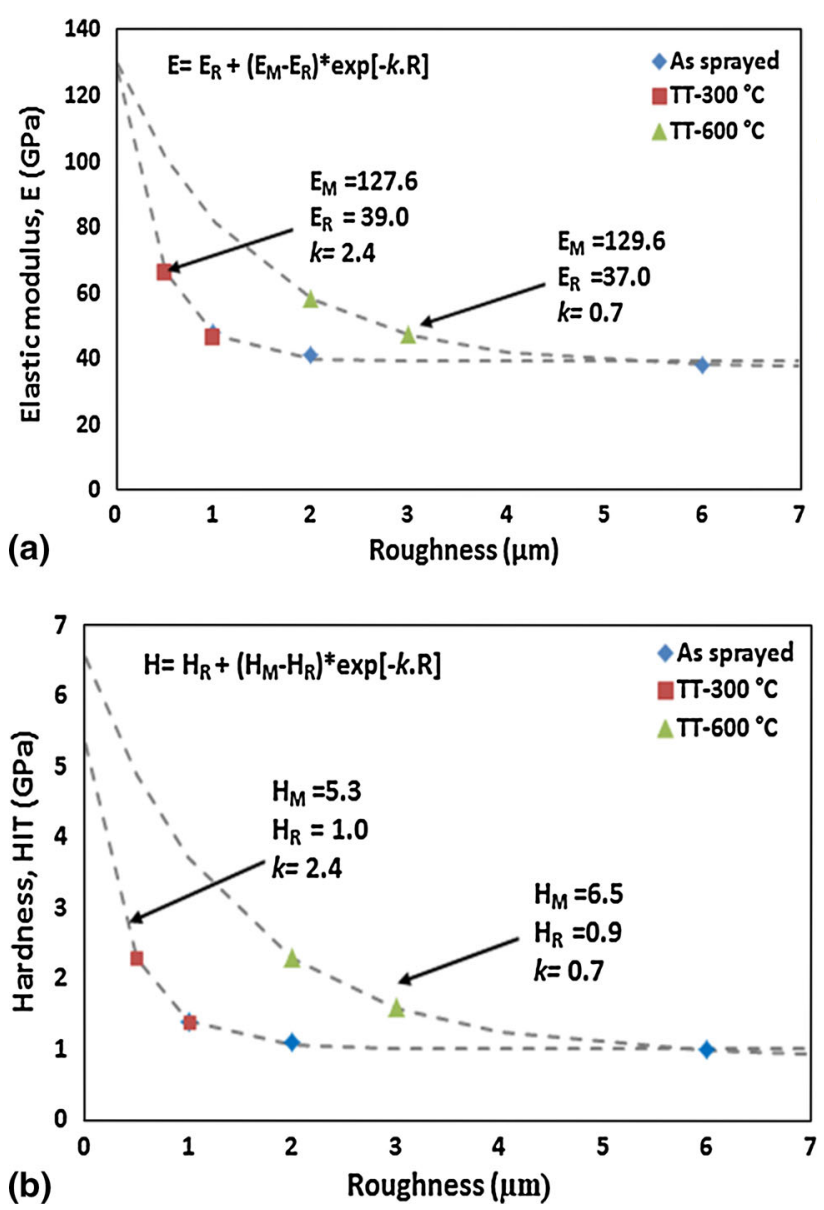

Fig. 6 Mechanical properties vs. the roughness for the as sprayed and heat treatment coatings: a elastic modulus, b hardness for every sample condition. It is noticeable that the two mechanical properties vary to a large extent with the indenter displacement for each indentation, which is due to the heterogeneity of the coating. It is important to mention that because of the high variation between the indentations per sample it has been suggested a methodology to obtain the intrinsic values for the samples studied, that will be presented in next paragraphs (Table 3).

In order to explain the behavior of the curves showed in Fig. 5, it can be proposed that for the case of test no. 1, if the material is dense or found a region of well-melted particles very close to the top surface, both mechanical properties have a high value close to that reported by Vert et al. (Ref 32) for nanostructured YSZ coatings. However, as the indentation depth increases and if the indenter meets a pore or a region of unmelted particles, the apparent values of these mechanical properties can decrease drastically. High properties values for melted and low values for unmelted particles in YSZ nanostructured coatings are mentioned in different investigations (Ref 33, 34).

In contrast, for the cases of tests no. 2 and 3 shown in Fig. 5, if such unmelted particles and defects are very close to the external surface of the material, the values of the mechanical properties are very low. For these two situations, when the indenter penetrates into the material, the change in hardness with indentation depth can take different shapes, according to the nature of particles and the presence of pores located in the neighborhood of the plastic zone below the indenter. Accordingly, as can be observed in Fig. 5, an increase or decrease in these mechanical properties will take place, because of the heterogeneity of the coatings. Independent of such variations, it is noted that the evolution of the elastic modulus and hardness with indentation depth exhibits some similarities.

As was mentioned previously, the analysis of the actual mechanical properties of the YSZ coating requires a cautious methodology. To circumvent such a problem, it is proposed that the computation of the values of the elastic

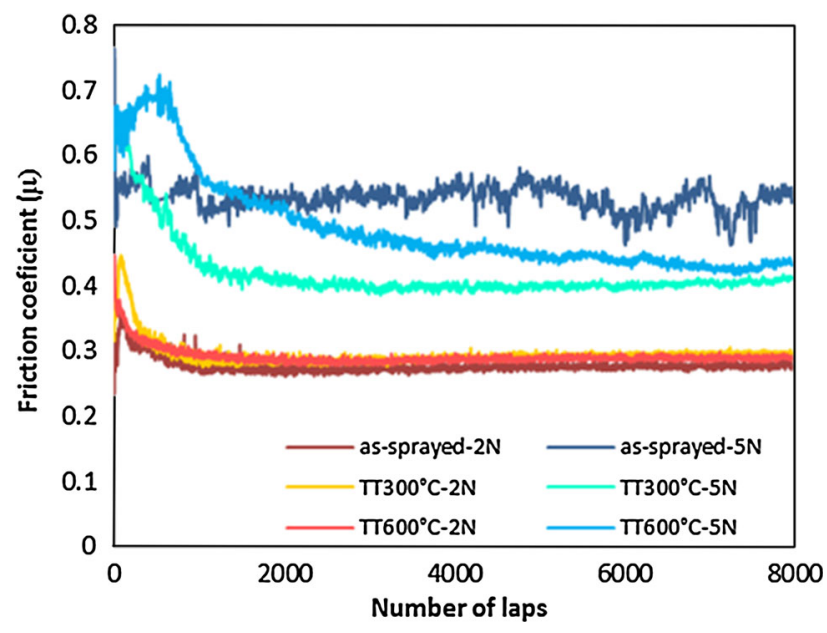

Fig. 7 Evolution of the friction coefficient with number of laps 
Table 4 Results of the pin-on-disc tests conducted on the YSZ coatings

\begin{tabular}{|c|c|c|c|c|c|c|c|c|}
\hline Condition & Temp ${ }^{\circ} \mathrm{C}$ & $\begin{array}{l}\text { Radius, } \\
\text { mm }\end{array}$ & $\begin{array}{l}\text { Load, } \\
\mathbf{N}\end{array}$ & $\underset{\mathbf{m}}{\text { Sliding distance, }}$ & $\begin{array}{l}\text { Volume, } \\
10^{8}{\mu \mathrm{m}^{3}}^{2}\end{array}$ & $\begin{array}{l}\text { STD, } \\
10^{7} \mu^{3}\end{array}$ & 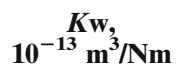 & $\begin{array}{c}\text { STD, } \\
10^{-14} \mathrm{~m}^{3} / \mathrm{Nm}\end{array}$ \\
\hline AS & 25 & 10 & 2 & 500 & 1.0 & 2.3 & 1.0 & 2.3 \\
\hline TT $-300^{\circ} \mathrm{C}$ & & & & & 1.8 & 4.0 & 1.8 & 4.0 \\
\hline TT $-600{ }^{\circ} \mathrm{C}$ & & & & & 1.7 & 5.7 & 1.7 & 5.7 \\
\hline AS & & 6 & 5 & 300 & 2.9 & 2.3 & 1.9 & 1.5 \\
\hline TT- $300^{\circ} \mathrm{C}$ & & & & & 3.3 & 1.6 & 2.2 & 1.1 \\
\hline TT $-600{ }^{\circ} \mathrm{C}$ & & & & & 4.1 & 7.7 & 2.7 & 7.7 \\
\hline
\end{tabular}

modulus and the hardness is carried out at given indenter displacements $(500,1000,1500$ and $2000 \mathrm{~nm})$, as indicated by the doted vertical lines in Fig. 5. Subsequently, the mean values and the standard deviations at the mentioned displacements can be calculated considering all the indentations done on each sample (AS, heat-treated, nonpolished, polished). The results are summarized in Table 3 .

Irrespective of the conditions and of the roughness values of the coatings, it is observed that the mean values are nearly constant as a function of the indenter displacements, whereas the standard deviation varies to a great extent showing that the material is strongly heterogeneous and that the measurement of the mechanical properties depends on the nature of particles and the porosity of the coating. If it is assumed that the values of the mechanical properties are independent of the indentation depth, because of the similitude between the values obtained at the different indenter displacements indicated previously, the elastic modulus and hardness could be plotted as a function of the roughness, as shown in Fig. 6 .

In Fig. 6, it can be observed that the mean mechanical properties summarized in Table 3 decrease as the coating roughness increases. Jointly with the values indicated in Table 3 , it is noticeable that the mechanical properties obtained for the coating heat-treated at $600{ }^{\circ} \mathrm{C}$ have higher values at a given roughness, in comparison with the AS coating and the coating treated at $300{ }^{\circ} \mathrm{C}$, whose values varied in a similar manner. These results allow the separation of the three sets of coatings in two different groups, as shown in Fig. 6. One group comprises the AS material together with the heat-treated samples at $300{ }^{\circ} \mathrm{C}$, where no appreciable difference have been observed in terms of mechanical properties. The second group corresponds to the heat-treated coatings at $600{ }^{\circ} \mathrm{C}$. In Table 3 , it can be observed that the AS coating without any prior polishing and heat treatment exhibits the highest roughness and has the lowest values of both elastic modulus and hardness. To explain such a variation, an association of the affected zone by the indentation process to the degree of the coating porosity could be made. Thus, it can be assumed that polishing leads to a blockage of the pores by the particles resulting from this process. In this case, the indented zone of the material becomes denser and the mechanical properties exhibit higher values, which are related to the nature of the particles (melted or unmelted). In order to represent the variation of both of the elastic modulus and the hardness with roughness, a simple parametric relationship of the form:
$P=P_{R}+\left(P_{M}-P_{R}\right) \cdot \exp [-k \cdot R]$,

has been suggested. In Eq (4), $P$ represents the elastic modulus or hardness evaluated experimentally, $P_{\mathrm{R}}$ is the initial mechanical property of the coating at high values of $\mathrm{Ra}$ (without polishing), $P_{\mathrm{M}}$ the intrinsic mechanical property and $k$ a factor related to the curvature of this variation. This factor represents the inverse of the porosity for which the ratio $\left(P-P_{\mathrm{R}}\right) /\left(P_{\mathrm{M}}-P_{\mathrm{R}}\right)=0.368$, that is to say, when the difference between the measured mechanical property and the mechanical property corresponding to the rough coating achieves approximately $37 \%$ of the maximum difference between both parameters, $\left(P_{\mathrm{M}}-P_{\mathrm{R}}\right)$.

Such an approach has been applied to represent the elastic modulus and hardness variation versus the roughness, as shown in Fig. 6 by the dotted lines, where a satisfactory description of the experimental data can be observed. For the fitting, the three parameters, i.e. $P_{\mathrm{R}}, P_{\mathrm{M}}$ and $k$ are determined following a free optimization procedure, that is to say, without imposing any restrictions. As a result, it is noted that for the same group of samples the parameter $k$ takes similar values for the elastic modulus and hardness variation, which shows that these two properties tend to vary in a similar manner as observed in Fig. 5. In addition, whatever the condition of the coating, the intrinsic elastic modulus of the corresponding material has a value of approximately $130 \mathrm{GPa}$ as already mentioned by Vert et al. (Ref 32), who found similar values depending on the thermal spraying conditions.

In the case of the hardness values, it was found that for the AS and heat-treated samples at $300{ }^{\circ} \mathrm{C}$, the intrinsic hardness has a value of approximately $5.3 \mathrm{GPa}$ and that this property increased to approximately $6.6 \mathrm{GPa}$ after heat treating the coating at $600{ }^{\circ} \mathrm{C}$. These results show that the heat treatment has an effect on the hardness behavior of the material, which could also affect its tribological behavior.

\subsection{Tribological Features}

The evolution of the friction coefficient $(\mu)$ of the YSZ coatings measured at room temperature and different loads is shown in Fig. 7. The average values of $\mu$ fluctuate with the normal load applied during the test. At a normal load of $2 \mathrm{~N}$, it was of approximately 0.3 , whereas at $5 \mathrm{~N}$ it varied between 0.4 and 0.6 . At $5 \mathrm{~N}$, the variation of the friction coefficient of the AS and heat-treated samples is noticeable. For all the tested samples and independently of the test loads, the friction coefficient initially decreases 

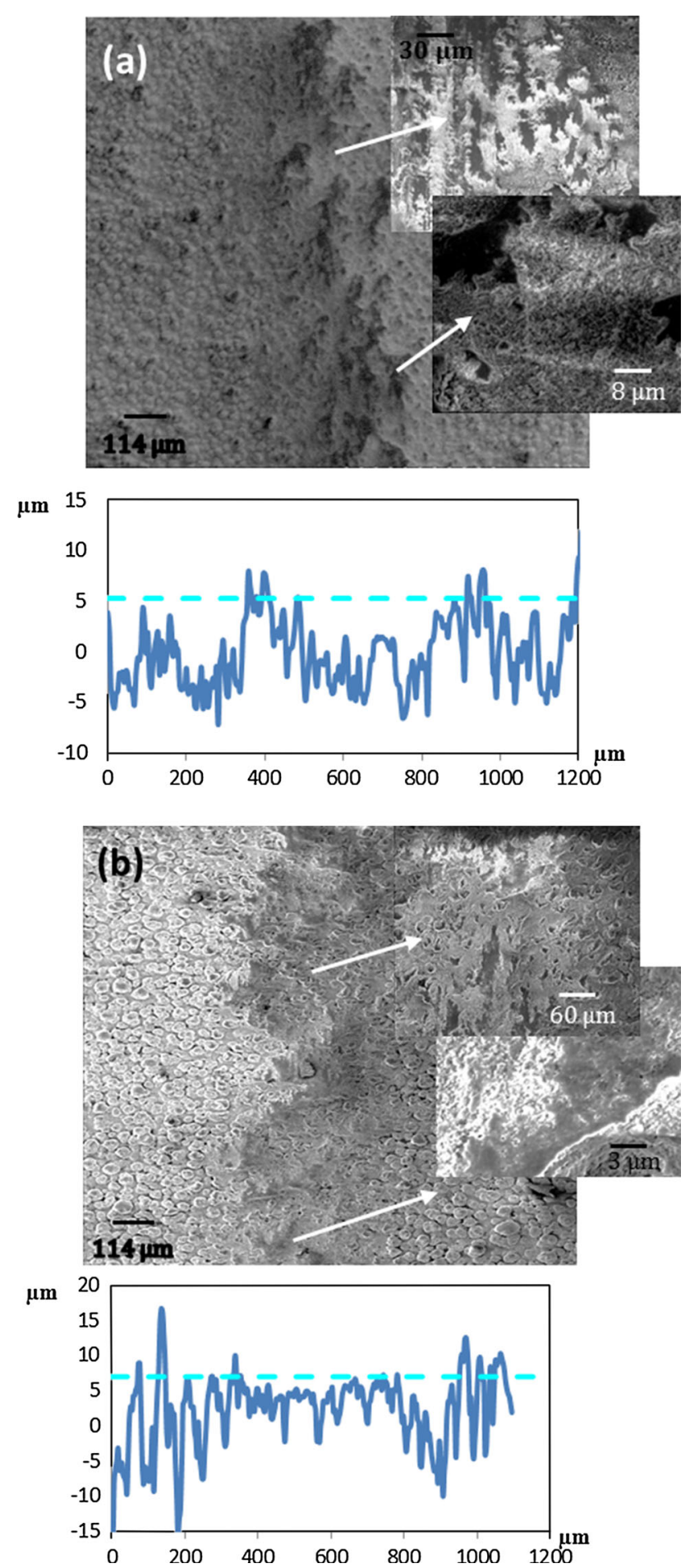

Fig. 8 SEM morphology of the wear tracks after the tests carried out at a $2 \mathrm{~N}$ normal load and the corresponding linear profile: a as-sprayed, $\mathbf{b}$ TT- $600{ }^{\circ} \mathrm{C}$

and then stabilizes as the number of laps increases. It is believed that this behavior is related to the smoothing of the surface, exhibiting a lower roughness $(1-3 \mu \mathrm{m})$. Similar considerations were reported by Ramachandran et al. (Ref 35). However, an increase in the friction coefficient with normal load can also be observed as a consequence of the higher amount of debris generated from the worn surfaces during the sliding wear tests.

The mean worn volumes and wear constants $\left(K_{\mathrm{w}}\right)$ are reported in Table 4. The results reveal that the heat treatments have a detrimental effect on the tribological behavior of the samples, especially noticeable for the samples tested at a $5 \mathrm{~N}$ normal load, for which the tested coatings have undergone more severe damage in comparison with those tested at $2 \mathrm{~N}$.

Optical profilometry measurements taken on the wear tracks produced on the coating surfaces after testing under a $2 \mathrm{~N}$ normal load revealed slight differences in both wear volumes and wear constant values between the three conditions of the tested samples. Apparently, at $2 \mathrm{~N}$ normal load, both heat treatments have a negative effect on the wear resistance of the YSZ. However, for the sample heat-treated at $600{ }^{\circ} \mathrm{C}$, which could go through variations in phase composition, as well as in the residual stress values, the wear damage produced in the tests performed at $2 \mathrm{~N}$ could be mitigated slightly due to its increase in hardness. Nevertheless, the tests carried out at $5 \mathrm{~N}$ have shown that AS and TT-300 ${ }^{\circ} \mathrm{C}$ samples had a similar tribological response, whereas the coating $\mathrm{TT}-600{ }^{\circ} \mathrm{C}$ exhibited the worst wear resistance, as can be seen in Table 4.

The values of the wear constants of the samples tested employing 2 and $5 \mathrm{~N}$ normal loads were approximately in the range of $10^{-13} \mathrm{~m}^{3} / \mathrm{Nm}$, indicating a smaller wear resistance of these coatings as compared to the results reported by Darut et al. (Ref 14). These authors found lower wear constants ranging from $3.4 \times 10^{-15}$ to $1.3 \times 10^{-13} \mathrm{~m}^{3} / \mathrm{Nm}$ at $5 \mathrm{~N}(20,000$ laps $)$ for a porous coating and $10^{-14} \mathrm{~m}^{3} / \mathrm{Nm}$ for dense YSZ coatings deposited by SPS, tested against an alumina counterpart of $6 \mathrm{~mm}$ diameter. Nevertheless, it has to be pointed out that these results corresponded to coatings composed of tetragonal phase only.

The higher wear constants obtained in the present work could therefore be attributed mainly to the presence of a cubic phase in the coating composition, as shown above from the XRD results. The cubic zirconia-based coatings exhibit relatively lower fracture toughness $\left(2.4 \mathrm{MPa} \mathrm{m}^{1 / 2}\right)$ (Ref 36, 37), which is generally associated with a lower performance of materials during wear tests. Moreover, the humidity during the test $(50 \pm 10 \%)$ could negatively affect the tribological performance of coatings, increasing the wear rate in comparison to the values obtained in a dry nitrogen environment as mentioned in (Ref 19). This could promote intergranular fracture due to embrittlement by the chemical adsorption of water, as a consequence of the well-known tendency of oxide ceramics to form hydroxylic surfaces (Ref 38-40). The factors mentioned above counteract the expected good tribological behavior associated with the nanostructure nature of these coatings.

SEM micrographs of the wear tracks and their corresponding profiles are shown in Fig. 8 and 9 for normal loads of 2 and $5 \mathrm{~N}$, respectively. The morphology of the wear tracks corresponding to the tests carried out at a $2 \mathrm{~N}$ normal load indicates a smoothing of the surface due to 

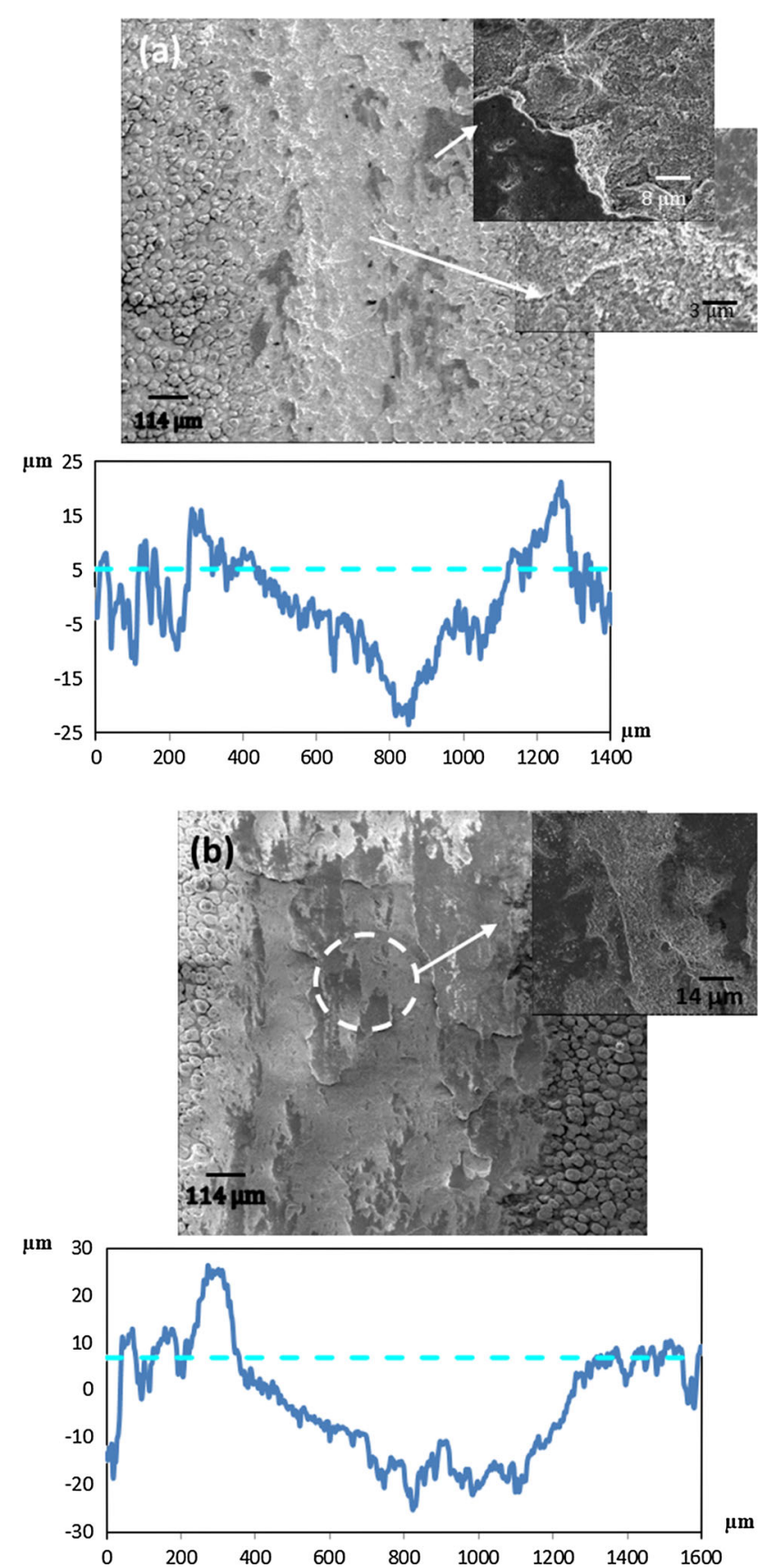

Fig. 9 SEM morphology of the wear tracks after the tests carried out at a $5 \mathrm{~N}$ normal load and the corresponding linear profile, a as-sprayed, b TT- $600{ }^{\circ} \mathrm{C}$

the removal of asperities, blocking of pores and formation of islands of compacted and/or smeared wear debris particles, corresponding to the darkest areas on the micrographs. Also, smoothing could due to brittle fracture of the material, as a consequence of an abrasive process initially of two bodies and then of three bodies because of the production of debris (see Fig. 8).

In the detailed micrograph taken at higher magnifications, corresponding to the sample heat-treated at $600{ }^{\circ} \mathrm{C}$

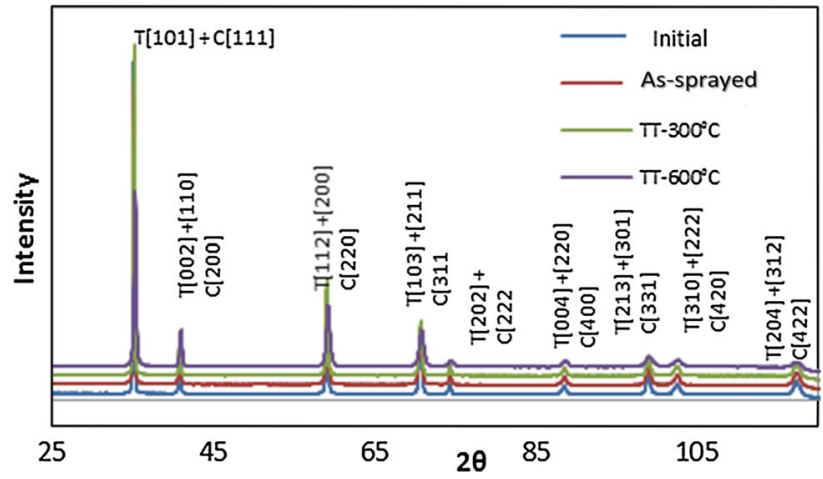

Fig. 10 Comparison between the XRD patterns for samples assprayed and heat treated after the wear tests

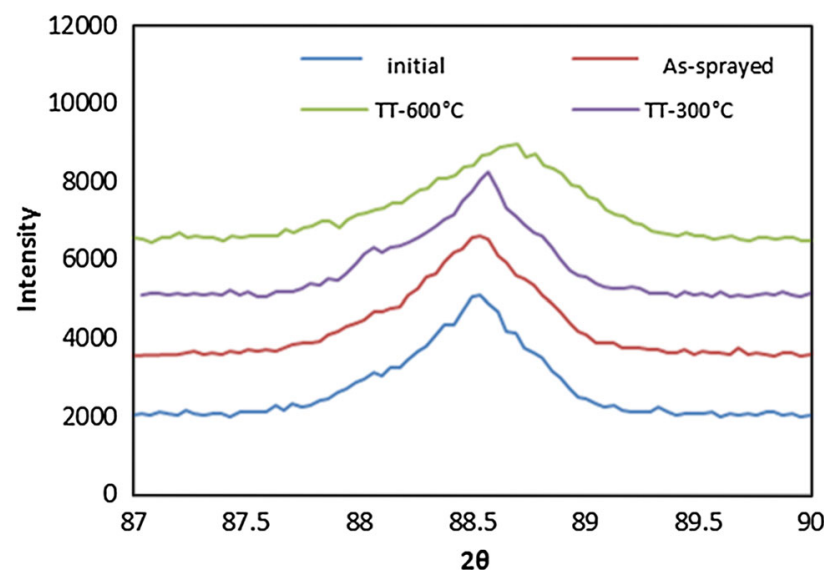

Fig. 11 Detailed X-ray diffraction pattern in the region of the diffraction angles $2 \Theta=87^{\circ}$ to $90^{\circ}$ for the as-sprayed and heattreated samples after the wear tests

and tested at $2 \mathrm{~N}$, it is interesting to observe the fact that its morphology still shows the presence of some grains corresponding to its initial surface morphology, indicating that a slight increase in hardness probably took place at this temperature, as compared to the other samples conditions.

At a $5 \mathrm{~N}$ applied normal load, all these processes are intensified and the worn surfaces exhibit a higher amount of abrasive mechanisms coupled with fatigue, owing to the cyclic load applied, therefore leading to severe fracture and grain pull-out with the production of a larger amounts of fine and irregular wear debris over and outside of the tribocontact areas. Under these conditions, the heat treatment at $600{ }^{\circ} \mathrm{C}$ gives rise to a negative effect on the wear behavior of the YSZ coatings, increasing the size of wear track as shown in Fig. 9. The EDS analysis carried out over the surface of the wear tracks identified only the elements corresponding to the $\mathrm{YSZ}$ coating ( $\mathrm{Y}, \mathrm{Zr}$ and $\mathrm{O}$ ).

In general, the following wear mechanism could be postulated: during the sliding wear tests the ball or alumina counterpart, which is harder than the coating $(H=21 \mathrm{GPa})$, progressively crushes the grains on the surface, giving rise to the presence of debris due to brittle 
fracture and fatigue. The applied load may induce decohesion of particles causing their detachment from the coating and, therefore, becoming a three-body abrasive mechanism (Ref 35). The coating material, removed as debris, could either be ejected from the wear track or could be embedded into it, forming islands of compacted particles adherent in the region of the tribological contact. After this process, grooved wear tracks are formed, as shown by the linear profiles. With the increase in load, the process is intensified and, therefore, the width and depth of the wear tracks increase and a higher amount of debris is observed at the edge of the tracks. The XRD patterns shown in Fig. 10 correspond to all the worn samples and reveal the presence of only the tetragonal and cubic phases. For higher precision, the XRD pattern was evaluated in the $2 \Theta$ region between $87^{\circ}$ and $90^{\circ}$ as indicated in Fig. 11. The XRD patterns of the worn sample showed no evidence of the presence of the monoclinic phase, suggesting that no transformation toughening mechanism occurred during the wear test, a result which confirms the presence of non-transformable tetragonal phases $\left(t^{\prime}+t^{\prime \prime}\right)$, as discussed above. (Ref 29, 30, 41, 42).

The spectrum of the AS worn sample exhibits a very similar pattern in comparison with that corresponding to the initial AS specimen, since just a small broadening of the principal peak is observed. This behavior is comparable to the shape of the pattern corresponding to the sample heat-treated at $300{ }^{\circ} \mathrm{C}$, with the difference that the peak at $2 \Theta=88.5^{\circ}$ is slightly displaced to the right.

However, from the XRD spectrum corresponding to the TT- $600{ }^{\circ} \mathrm{C}$ sample, it can be observed that all the peaks exhibit a higher broadening, as well as a reduction of their intensities and a slight displacements to the right. The registered modification in all the peak intensities could be related to a variation in crystal structure, i.e. a change in the atomic positions at the unit cell as a consequence of thermal vibration. In contrast, the broadening of the peaks could, in general, be associated with a decrease in the crystallite size and microstrain influenced by non-uniform lattice strain and defects. The displacements to the right could be attributed to a decrease in the lattice parameter and a change in macrostrains, which is a uniform strain that produces the distortion of the crystal lattice because an imposed external load (Ref 42, 43). These findings could be related to the fact that the sample TT- $600{ }^{\circ} \mathrm{C}$ tested at a $5 \mathrm{~N}$ load showed the worst tribological behavior, since it is possible that after the heat treatment some changes in the crystal structure, lattice parameter, microstrain and in the values of the residual stresses could have taken place (Ref 43-45)

\section{Conclusions}

The tribological behavior and mechanical properties of nanostructured 8YSZ coatings deposited by SPS were studied and correlated with their morphological and microstructural characteristics. Also, the influence of the heat treatment at 300 and $600{ }^{\circ} \mathrm{C}$ on their microstructure and properties were evaluated.
The morphological characterization of the cross-section carried out by MEB revealed that the coatings are composed of a thin columnar layer at the interface substrate/ coating, followed by a granular morphology, due to the recoil phenomenon, with the presence of porosity and voids. The XRD analysis revealed the presence of $c$ and $t^{\prime}+t^{\prime \prime}$ in the AS coating.

The morphology described directly affects the measurements of mechanical properties (elastic modulus and hardness) by nanoindentation, which exhibit a considerable variation due to the coating heterogeneity. It has been shown that the variation of these properties with coating roughness follows an exponential decay law similar for both parameters. The heat treatment carried out at $600{ }^{\circ} \mathrm{C}$ gave rise to a slight increase in hardness to $\sim 6.5 \mathrm{GPa}$, as compared to the value of $5.3 \mathrm{GPa}$ determined for the other two conditions: AS and heat-treated at $300{ }^{\circ} \mathrm{C}$. However, concerning the modulus of elasticity, an approximate value of $130 \mathrm{GPa}$ was found regardless of the sample condition.

Moreover, the tribological characterization resulted in a severe wear regime $\left(>10^{-4} \mathrm{~mm}^{3} / \mathrm{Nm}\right)$ for all the samples under study, as mentioned by Kato and Adachi (Ref 46). The wear volumes and wear constants have revealed that heat treatments conducted at 300 and $600{ }^{\circ} \mathrm{C}$ had a negative influence on the tribological behavior of the coated systems. The morphology of the wear tracks has shown evidence of brittle fracture in combination with an abrasive wear process and fatigue. These mechanisms are accompanied by the smoothing of the surfaces and blocking of pores, grain pull-out and formation of islands of compacted and/or smeared wear debris.

The obtained severe wear regime could be related to the existence of the cubic phase in the coatings, together with the humidity present during the wear tests $(>50 \%)$, both of which counteract the expected good tribological behavior associated with the nanostructure nature of the coatings. In addition, the XRD pattern obtained after the tribological tests indicated that heat treatment at $600{ }^{\circ} \mathrm{C}$ could probably produce changes in crystal structure, as a reduction of the lattice parameter, changes in micro- and macrostrains, a uniform strain that produces the distortion of the crystal lattice because of an imposed external load on the residual stresses. All these variations negatively affected the wear behavior of the coated systems.

\section{Acknowledgements}

The present investigation has been carried out with the support of the Scientific and Humanistic Development Council of the Universidad Central de Venezuela (CDCH-UCV) through the Projects No AIB-08-85-392012 and PG-08-8645-2013. Ms. S. Kossman gratefully acknowledges the financial support through the scholarship "Stages Master "received from University of Lille 1 to carry out part of the experiments in LML UST Lille and Arts et Métiers ParisTech, MSMP, Lille, France. Professor Puchi acknowledges the financial support of the Conseil Régional Nord-Pas de Calais, France through the International Chair Program 2011. 


\section{References}

1. J.R. Davis, Protective Coatings for Superalloys. ASM Specially Handbook, Heat-Resistance Materials. ASM International Materials Park, OH. 1997, p 335-344

2. O. Tingaud, R. Etchart-Salas, V. Rat, J.F. Coudert, H. Ageorges, A. Grimaud, A. Denoirjean, P. Fauchais, G. Montavon, N. Caron and S. Alexandre, Suspension Plasma Spraying of Zirconia Coatings: Process and Coating Structure, 18th International Symposium on Plasma Chemistry, Japan, 2007

3. G. Darut, F. Ben-Ettouil, A. Denoirjean, G. Montavon, H. Ageorges, and P. Fauchais, Dry Sliding Behavior of Sub-Micrometer-Sized Suspension Plasma Sprayed Ceramic Oxide Coatings, J. Therm. Spray Technol., 2010, 19(1-2), p 275285

4. S.C. Tjong and H. Chen, Nanocrystalline Materials and Coatings, Mater. Sci. Eng. R, 2004, 45(1-2), p 1-88

5. Y. Zeng, S.W. Lee, L. Gao, and C.X. Ding, Atmospheric Plasma Sprayed Coatings of Nanostructured Zirconia, J. Eur. Ceram. Soc., 2002, 22(3), p 347-351

6. L. Pawlowski, Finely Grained Nanometric and Submicrometric Coatings by Thermal Spraying, Surf. Coat. Technol., 2008, 202(18), p 4318-4328

7. M. Gell, Application Opportunities for Nonostructured Materials and Coatings, Mater. Sci. Eng., 1995, 204(1), p 246-251

8. P. Fauchais and A. Vardelle, Solution and Suspension Plasma Spraying of Nanostructured Coatings. In H. Salimi Advanced Thermal Spray Applications, Ed. InTech, 2012, Chapter 7

9. E. Brousse, G. Montavon, P. Fauchais, A. Denoirjean, V. Rat, J.-F.Coudert, and H. Ageorges, Thin and Dense Yttria-Partially Stabilized Zirconia Electrolytes for IT-SOFC Manufactured by Suspension Plasma Spraying, Thermal Spray 2008: Crossing Borders (DVS-ASM), 2008, p 535-540

10. O. Tingaud, A. Grimaud, A. Denoirjean, G. Montavon, V. Rat, J.-F.Coudert, P. Fauchais, and T. Chartier, Suspension PlasmaSprayed Alumina Coating Structures: Operating Parameters vs. Coating Architecture, Thermal Spray 2008: Crossing Borders (DVS-ASM), 2008, p 311-316

11. L. Pawlowski, Suspension and Solution Thermal Spraying Coatings, Surf. Coat. Technol., 2009, 203, p 2807-2829

12. A. Bacciochini, G. Montavon, J. Llavsky, A. Denoirjean, and P. Fauchais, Porous Architecture of SPS Thick YSZ Coatings at the Nanometer Scale $(\sim 50 \mathrm{~nm})$, J. Therm. Spray Technol., 2010, 19(1-2), p 198-206

13. R. Vert, P. Carles, E. Meillot, E. Laborde, G. Mariaux, and A. Vardelle, Adhesion of Ceramic Coating on Thin and Smooth Metal Substrate: A Novel Approach with a Nanostructured Ceramic Interlayer, J. Therm. Spray Technol., 2012, 21(6), p 1128-1134

14. G. Darut, H. Ageorges, A. Denoirjean, and P. Fauchais, Tribological Performances of YSZ Composite Coatings Manufactured by Suspension Plasma Spraying, Surf. Coat. Technol., 2013, 217, p $172-180$

15. C. Piconi and G. Maccauro, Zirconia as a Ceramic Biomaterial, Biomaterials, 1999, 20, p 1-25

16. R. Hannink, P. Kelly, and B. Muddle, Transformation Toughening in Zirconia-Containing Ceramics, J. Am. Ceram. Soc., 2000, 83(3), p 461-487

17. S. Tao, B. Llang, C. Ding, H. Llao, and C. Coddet, Wear Characteristics of Plasma-Sprayed Nanostructured Yttria Partially Stabilized Zirconia Coatings, J. Therm. Spray Technol., 2004, 14(4), p 518-523

18. H. Ahn, J. Kim, and D. Lim, Tribological Behavior of Plasma Sprayed Zirconia Coatings, Wear, 1997, 203(204), p 77-87

19. T.E. Fischer, M.P. Anderson, S. Jahanmir, and R. Salher, Friction and Wear of Tough and Brittle Zirconia in Nitrogen, Air, Water, and Hexadecadene Containing Stearic Acid, Wear, 1988, 124, p 133-148
20. J.H. Ouyang and S. Sasaki, Unlubricated Friction and Wear Behavior of Low-Pressure Plasma-Sprayed $\mathrm{ZrO}_{2}$ Coating at Elevated Temperatures, Ceram. Int., 2001, 27, p 251-260

21. A. Erdemir, A Review of the lubrication of ceramics with thin solid films. Friction and Wear of Ceramics, S. Jahanmir, Ed., Marcel Dekker, 1994, p 119-161

22. J. Ilavsky and J.K. Stalick, Phase Composition and Its Changes During Annealing of Plasma-Sprayed YSZ, Surf. Coat. Technol., 2000, 127, p 120-129

23. W.C. Oliver and G.M. Pharr, Improved Technique for Determining Hardness and Elastic Modulus Using Load and Displacement Sensing Indentation Experiments, J. Mater. Res., 1992, 7(6), p 1564-1580

24. W.C. Oliver and G.M. Pharr, Measurement of Hardness and Elastic Modulus by Instrumented Indentation: Advances in Understanding and Refinements to Methodology, J. Mater. Res., 2004, 19(1), p 3-20

25. K. VanEvery, M. Krane, R. Trice, H. Wang, W. Porter, M. Besser, D. Sordelet, J. Ilavsky, and J. Almer, Column Formation in Suspension Plasma-Sprayed Coatings and Resultant Thermal Properties, J. Therm. Spray Technol., 2011, 20, p 817-828

26. R. Vert, Elaboration Par Projection Plasma d'un revêtement céramique sur un substrat métallique mince et de faible rugosité : Usage d'une sous-couche d'adhérence nanostructurée. PhD thesis, Université de Limoges, 2011, (in French)

27. D.N. Argyriou and C.J. Howard, Reinvestigation of YttriaTetragonal Zirconia Polycrystal (Y-TZP) by Neutron Powder Diffraction-A Cautionary Tale, J. Appl. Crystallogr., 1995, 28, p 206-208

28. R. Srinivasan, R. De Angelis, G. Ice, and B. Davis, Identification of Tetragonal and Cubic Structures of Zirconia Using Synchrotron X-Radiation Source, J. Mater. Res., 1991, 6, p 12871292

29. J. Swab, Role of Oxide Additives in Stabilizing Zirconia for Coating Applications, Army Research Laboratory, 2001, ARL-TR-2591

30. X. Xing, Thesis: Computational modeling study of yttria stabilized zirconia. PhD thesis. University College of London, 2010

31. S. Giraud and J. Canel, Young's Modulus of Some SOFCs Materials as a Function of Temperature, J. Eur. Ceram. Soc., 2008, 28, p 77-83

32. R. Vert, D. Chicot, C. Dublanche-Tixier, E. Meillot, A. Vardelle, and G. Mariaux, Adhesion of YSZ Suspension Plasma-Sprayed Coating on Smooth and Thin Substrates, Surf. Coat. Technol., 2010, 205, p 999-1003

33. R.S. Lima, A. Kucuk, and C.C. Berndt, Bimodal Distribution of Mechanical Properties on Plasma Sprayed Nanostructured Partially Stabilized Zirconia, Mater. Sci. Eng., 2002, A327, p 224-232

34. P. Carpio, E. Rayón, L. Pawłowski, A. Cattini, R. Benavente, E. Bannier, M.D. Salvador, and E. Sánchez, Microstructure and Indentation Mechanical Properties of YSZ Nanostructured Coatings Obtained by Suspension Plasma Spraying, Surf. Coat. Technol., 2013, 220, p 237-243

35. C.S. Ramachandran, V. Balasubramanian, P.V. Ananthapadmanabhan, and V. Viswabaskaran, Understanding the Dry Sliding Wear Behaviour of Atmospheric Plasma-Sprayed Rare Earth Oxide Coatings, Mater. Des., 2012, 39, p 234-252

36. S. Jahanmir, Advanced Ceramics in Tribological Applications. Friction and Wear of Ceramics, S. Jahanmir, Ed., Marcel Dekker, 1994, p 3-12

37. S.T. Aruna, N. Balaji, and K.S. Rajam, Phase Transformation and Wear Studies of Plasma Sprayed Yttria Stabilized Zirconia Coatings Containing Various mol\% of Yttria, Mater. Charact., 2011, 62, p 697-705

38. S.M. Wiederhorn, S.W. Freiman, E.R. Fuller, and C.J. Simmons, Effect of Water and Other Dielectrics on Crack Growth, J. Mater. Sci., 1982, 17, p 3460-3478

39. T.A. Michalske and B.C. Bunker, Slow Fracture Model Based on Strained Silicate Structures, J. Appl. Phys., 1984, 56, p 2686 
40. R.K. Iler, The Chemistry of Silica, Wiley, New York, 1979, p 896

41. S. Nazarpour, C. López-Gándaraa, C. Zamania, J.M. FernándezSanjuán, F. Ramos, and A. Cirera, Phase Transformation Studies on YSZ Doped with Alumina. Part 2: Yttria Segregation, J. Alloys Compd., 2010, 505, p 534-554

42. G. Witz, V. Shklover, W. Steurer, S. Bachegowda, and H. Bossmann, Phase Evolution in Yttria-Stabilized Zirconia Thermal Barrier Coatings Studied by Rietveld Refinement of X-Ray Powder Diffraction Patterns, J. Am. Ceram. Soc., 2007, 90(9), p 2935-2940
43. B.D. Cullity, Elements of X-Ray Diffraction, 2nd ed., AddisonWesley, Boston, 1978

44. S. Kuroda, T. Dendo, and S. Kitahara, Quenching Stress in Plasma Sprayed Coatings and Its Correlation with Deposit Microstructure, J. Therm. Spray Technol., 1995, 4(1), p 75-84

45. A. Macwan. Residual Stresses in Suspension Plasma Sprayed Electrolytes in Metal-Supported Solid Oxide Fuel Cell. Master thesis. Ryerson University, Canada, 2012

46. K. Kato and K. Adachi, Wear Mechanisms. Modern Tribology Handbook Vol. I, B. Bhushan, CRC, 2001, Chapter 7 